\title{
第26回群馬脳腫瘍研究会記録
}

\section{第一部 germinoma}

\section{座長 小野 伸夫（堀江病院）}

1. 春髄硬膜外転移を来した germinoma の一例 登坂 雅彦, 林

悟, 長屋 孝雄 （前橋脳神経外科病院）

大宜見綱夫, 伊藤

潤，伊藤 秀明

（前橋赤十字病院）

小野 伸夫

(堀江病院脳神経外科)

頭蓋内 germinoma は脊髄播種を起こし得るが. 硬膜内 髄外腫揚として認められ，硬膜外転移は極めて稀である. 症例は 17 歳男性, 1998 年 12 月 15 日複視を訴元来院, MRI 上よく造影される松果体腫瘍と水頭症を認めた. VP shunt 後, 全脳 $30 \mathrm{~Gy}$, 局所 20Gy の照射治療が行われ た。 20Gy 終了時に著明な腫愓の縮小を認め, HCG や AFP は陰吽，germinoma の臨床診断であったが， MRI 上, 若干の造影の残存を認めていた. 無症状で通学して いたが，2000 年 1 月 31 日外来にて軽い両下肢のしびれ 感を訴えた. 1 週間後, 両下肢の脱力と, 排尿障害を訴え 来院. MRI そて T12-L1 レベルに淡く造影され砂時計型 に発育する硬膜外腫瘍を認めた. 2 月 9 日摘出術施行, 灰 白色調の弾性軟の腫瘍は硬膜外飞腫瘤を形成, root sleeve を結紮切離, 摘出した. Shunt resorvoir から採取さ れた髄液は細胞診，腫瘍マーカー共に陰性。組織は germinoma で root sleeve の硬膜内に腫瘍細胞の充満がみら れた. 術後, 全春髄照射 24Gy と化学療法 (IFOS, CARB, VP16）を 3 コース行い，ほぼ無症状である. Germinoma の硬膜外転移は極めて稀であるが，急速な症状の進行を 呈する為, 注意が必要である.
日 時：平成 12 年 7 月 1 日

場 所：マーキュリーホテル

世話人：小野 伸夫 (堀江病院脳神経外科)

事務局：群馬大学脳神経外科 栗原 秀行

2. 術後自然消退した germinoma の一例

$\begin{array}{llr}\text { 堀口 } & \text { 桂志 } & \text { （桐生厚生総合病院） } \\ \text { 藤巻 } & \text { 広也, } & \text { 佐々木富男 } \\ \text { 木暮 } & \text { 修治 } & \text { (国立循環器病セン馬大学) }\end{array}$

今回我々は腫瘍部分摘出術後に自然退縮した傍松果体 部 germinoma の一例を経験した. 頭蓋内 germinoma が 経過中に自然退縮したという報告はまれであり，文献的 考察を加えて報告する.

【症 例】 22 歳 男性.

【主 訴】頭重感, 複視.

【現病歴】平成 11 年夏頃より複視を自覚, 同年 11 月頃 には他覚的にも眼球運動・眼位の異常認められたが放置. 平成 12 年 2 月に頭重感，食欲不振が出現. 2 月 25 日嘔 吐, 2 月 26 日一過性意識消失発作出現. 2 月 28 日近医に て CT 施行し pineal tumor, hydrocephalus 指摘され，同 日総合大田 Hp. 入院. 翌 2 月 29 日群馬大学脳神経外科 八紹介入院.

【入院時所見】意識清明 $(+)$, 右眼外転位, isocoria, 対光 反射両側消失, 垂直性眼球運動障害 $(+)$, 麻痺 $(-)$, 感覚 障害 $(-)$.

【画像所見】MRI ; tectum midbrain hypothalamus $に$ かけて $2.8 \times 3.1 \times 2.2 \mathrm{~cm}$ の enhancementされる mass あ り. 右側脳室前角上壁にも不整に enhancement $(+)$. 第IV 脳室を除く著名な脳室拡大あり。

【経 過】2月29日水頭症に対し Ommaya‘s reservoir setting 施行. 3 月 1 日より, 持続脳室ドレナージ施行 ( 3 月 29 日). 3 月 9 日 partial removal of the tumor (occipital transtentorial approach) 施行. 術 4 日後 MRI において腫 瘍の縮小を認めた，永久病理診断では gerninomaであっ た. 3 月 14 日より chemotherapy（カルボプラチン，エト ポシド) 1クール施行. また同日より radiation 施行 (全 脳 $30 \mathrm{~Gy}$, 局所 $16 \mathrm{~Gy}$; 計 $46 \mathrm{~Gy}) .4$ 月 25 日独歩退院と なった。

【退院時所見】cons. alert, headache $(+)$, anisocoria ; rt $<$ lt, light reflex; blt. absent, vertical gaze palsy 入院時 より改善するも残存, Parinaud sign (+), convergence 
$(一)$, paresis $(-)$, sensory disturbance $(-)$ 現在, 外来 フォローアップ中.

\section{3. 群馬大学脳神経外科病歴登録システムを用いた germ cell tumor の検索結果}

$\begin{array}{lr}\text { 甲賀 英明 } & \text { (利根中央病院) } \\ \text { 佐々木富男 } & \text { (群馬大学) }\end{array}$

【目的および方法】1967 年 6 月の群馬大学脳神経外科開 設以後の全病歴台帳は現在すべてファイルメーカープロ を用いデータベース化し, 疾患コードは 85 病名に分類 した. 2000 年 3 月末までの退院番号は 5900 番であり,一 患者につき脳神経外科病名が 3 件までコード化され登 録, 第 1-3 病名コードいずれかに記載されているもの すべてが検索されるようにスクリプトを作成した．この システムはあくまでも患者を検索し疾患リストを作成す る目的のものであるが, この範囲で検索を行った.

【結 果】全症例では脳腫瘍のべ 2,418 入院 $(1,799$ 症 例), 血管障害 $1,366(1,336)$, 外傷 662 (630), 小览先天奇形 572 (382), 脊椎脊髄 161 (138), 中枢神経感染症 112 (91), 機能的疾患 774 (666), 頭蓋骨・眼窩・頭皮疾患 143 (126), 術後その他 252 (159) 総計延べ 6,460 入院 $(5,327$ 症例) であった。

germ cell tumor はのべ 88 入院があり，疑いを含め 61 症例あり, 原発性脳腫瘍症例 1,649 例中 61 例 (3.75\%) で あった. 男性 46 例, 女性 15 例, 部位では松果体部 33 例 (男 29 例, 女 4 例), 鞍上部 18 例 (男 10 例, 女 8 例) 基底 核部 8 例 (男 7 例, 女 1 例), 部位記載なし 4 例, (double midline tumor 2 例) であった. 組織診断では生検または 細胞診での組織確定 37 例, 組織未確定 24 例で, 組織確 定されているものでは germonoma 24 例, embryonal carcinoma 4 例, teratoma 7 例, choriocarcinoma 2 例であっ た. 転帰は 61 症例山 18 例ひ死亡が確認されておうり, embryonal carcinoma $3 / 4$, choriocarcinoma $2 / 2$, teratoma $1 / 7$ germinoma $2 / 24$ 組織不明 $10 / 24$ 例で死亡が確認さ れている。

【考察】まだまだ問題点が多いシステムであるが, コード化され疾患リスト作成にきわめて有用なシステム と考える.ただし使用上はデー夕の verify が必要である.

\section{Germinoma 放射線療法の長期予後}

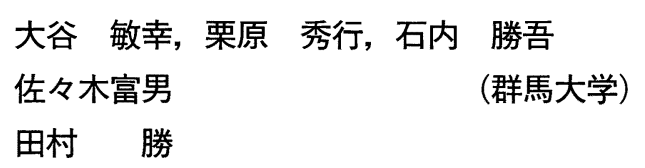

(公立藤岡総合病院健康管理センター)

【目 的】近年 germinoma 汶し化学療法を先行させ照 射線量を減らす試みが行われている，従来我々は松果体
部 germinoma が強く疑われた場合，手術を行わず約 50Gy 放射線療法を主体として治療してきた．その長期 予後について検討する.

【方 法】対象は 1980 年より 1998 年まで, CT, MRI, 腫 瘍マーカーにて松果体部 germinoma が強く疑われ, 当科 にて治療した 12 例 (8〜41 歳, 男性 11 人, 女性 1 人) で ある. 約 20Gy で腫瘍の放射線による反応をみた上で 50Gy の拡大局所照射を施行した. 1990 年までの例は照 射のみ, 1991 年以降は化学療法も併用した。

【結 果】約 20Gy の時点で腫瘍は著明に縮小した 10 例 はすべて再発はなく, 照射群, 照射十化学療法群ともに 長期的な予後は良好であった. 2 例で照射による縮小効 果が得られず，手術を要した， 1 例は embryonal carcinoma で 3 年 11 ケのの経過で死亡した。他の 1 例は glioblastoma で術後 11 日目に手術死亡した. 照射が著効 した 10 例のうち画像の経過観察をし得たのは 8 例で, そのうち 2 例 $(25 \%)$ に脳溝の拡大を認めた. 照射療法の ため内分泌学的補償療法を必要とする例はなかった.

【まとめ】20Gy で腫瘍の放射線による縮小をみた例は 生命予後は良好であった. 2 例 (16.7\%) に照射療法の途 中で手術を要しその予後は不良であった，照射療法にて $25 \%$ に脳溝の拡大を認めるものの, 臨床的に問題となる 内分泌学的異常はなかった.

\section{第 2 部 興味有る脳腫瘍症例}

\section{座長 楮本 清史 (埼玉県立がんセンター)}

\section{5 . 卵巣癌術後の小脳腫瘍の一例 \\ 狩野 友昭, 清水 庸夫}

（関東脳神経外科病院）

症例は 47 歳女性で, 平成 10 年 3 月より群馬県立がん センター婦人科にて卵巣癌の診断で手術, 化学療法を受 けていた. 組織診断は serous papillary adenocarcinoma であった. 平成 11 年 1 月頃より頭痛を訴え頭部 MRI を 施行し，小脳腫瘍を認め同年 4 月 30 日に当科紹介と なった. 来院時神経学的所見は意識清明で軽度体幹失調 を認めた，頭部 CT では小脳虫部より第 4 脳室にかけて $4 \times 2 \mathrm{~cm}$ 大 low density mass を認め, enhanceはされな かった. mass と第 4 脳室の境界は不明瞭であった. 頭部 MRI では小脳虫部より第 4 脳室を充満するように腫瘍 は増大し, T1 で low intensity, T2 で high intensiry で境 界は不明瞭で enhancement はされなかった. 脳血管撮影 像では PICA の偏位も少なく, 腫崵陰影も見られなかっ た. 腫瘍マーカーCA125 は有意に上昇を示していなかっ 
たが, 転移性脳腫瘍を疑い, 平成 11 年 5 月 21 日に腫瘍 摘出術を施行した. 手術は prone position で suboccipital approach で行った. 腫瘍は脳表に露出していた. vermis に主座を持ち, 主に白色調で一部黄色調を伴い, 硬さは geratinous soft, 出血性で境界は表層では比較的明瞭で あったが深部では不明瞭であったため摘出は部分摘出に とどめた. 術後経過は良好で平成 11 年 6 月 9 日独歩退 院となり, 平成 12 年 5 月術後 1 年で残存腫瘍の増大は 認めていない.

6. A case of solitary fibrous tumor in the frontal base. 楮本 清史, 富澤真一郎, 卯木 次郎 (埼玉県立がんセンター)

【症 例】 30 歳女性. 98 年 8 月, 右眼痛, 99 年 8 月, 頭痛, 眼のかすみを自覚. うっ血乳頭を指摘され当科初詅.

【神経所見】左嗅覚脱失, うっ血乳頭.

【MRI】篩板部より両側前頭葉内に進展する $5 \times 7 \times 9 \mathrm{~cm}$ の髄外腫湯の所見.

【T1 強調画像】低信号, FLAIR 像 : 低信号, 一部高信号, 増強効果 $(++)$. Peritumoral edema (軽度). Dural tail $\operatorname{sign}(-)$.

【CT】付着部骨肥厚像 $(-)$, blistering (-).

【脳血管撮影】外頸動脈系の関与 $(-)$. Hypovascular mass. $9 / 21$, 腫瘍摘出術.

【腫 瘍】赤褐色, 髄様 (一部弾性硬), 易出血性, 篩板部 から両側前頭葉内に明瞭な境界を持ち発育. 脳内腫瘍を
肉眼的に全摘し付着部には電気凝固.

【病理学的所見】比較的均一な短紡鍾形の腫場細胞が充 実性に増殖. 細胞は線維束を作りながら流れるように配 列, 様々な量の細胞間膠原線維. 核はほほ均一, 狭い細胞 質. 分裂像 $(+/-)$. whorl, psammoma body, 壊死, 血管増 殖像 (一).

【免疫組織学的所見】CD34 (+/-); EMA, S-100, GFAP, $\alpha$-SM-actin (-), MIB-1 index : $0-2 \%$.

【電顕所見】腫瘍細胞は紡錘形, 細胞内小器官が比較的 発達. Primitive junction $(+/-)$. Well-formed junction, interdigitation, 基底膜構造 (一).

【病理診断】solitary fibrous tumor (SFT). 放射線治療は 施行しなっかったが, 術後 9 か月後の現在, 再発の徴候 なし.

本症例は，前頭蓋底から発生した SFT と考えられる。 鑑別診断としては, 髄膜腫, 嗅神経芽腫等があげられる. 胸膜の紡錘形細胞腫瘍として報告されていた SFT は, ま れに髄膜に発生すること知られてきており今回報告す る.

\section{<指定発言〉}

Solitary fibrous tumor (orbita-middle fossa, regrowth case)

$$
\text { 林悟 }
$$

（前橋脳神経外科） 